\title{
EXPLORING CULTURAL DIFFERENCES IN HOSPITALITY SECTOR COMPETITIVENESS VIA ONLINE BIG DATA*
}

\author{
Taşkın DİRSEHAN** \\ Nurdan KÖSE*** \\ Eylül Eser ERÇEVİK**** \\ Sena CEYLAN ${ }^{* * * * *}$
}

\begin{abstract}
For 2014-2016, "Developing Marketing Analytics for a Data-Rich Environment" is determined as a "Tier 1 Priority" by the Marketing Science Institute (MSI). Understanding customers by analyzing their experiences is very important to build long-term and profitable relationships with them. In the hospitality sector, travelers create huge amounts of data called "big data" by sharing their experiences in travel websites. If these experiences are analyzed and transformed into information, they can provide a competitive advantage; thus, data mining tools are used to find hidden patterns and relationships in large data sets. So, the purpose of this paper is to explore the cultural differences in the hospitality sector with the help of big data. For this purpose, customers' online reviews are analyzed by using text mining, as a data mining tool, according to the factors based on positive and negative reviews collected from "booking.com" (1000 customer reviews, 500 for each city) for the hotels in London and Tokyo. Then, the findings are discussed according to Hertzberg's Two-Factor Theory of Motivation and the cultural differences. In addition, some managerial implications were given to hotel managers to enlighten them about gaining competitive advantage in their industry.
\end{abstract}

Keywords: Big Data; Text Mining; Hertzberg's Two-Factor Motivation Theory; Tourism Marketing

An earlier version of this paper was presented at $3^{\text {rd }}$ International Conference of Business Students (ICOBS'16) in Sakarya, Turkey, and published in the proceedings book under the title "Gaining Competitive Advantage through Big Data in the Hospitality Sector", and it won the best paper award at the conference.

** Asst.Prof., Marmara University, Faculty of Business Administration, Department of Business Administration (lectured in English), taskin.dirsehan@marmara.edu.tr.

*** Final year student at Marmara University, Faculty of Business Administration, Department of Business Administration (lectured in English), nurdi01@yahoo.com

**** Graduate from Marmara University in 2016, Faculty of Business Administration, Department of Business Administration (lectured in English), eylulercevik@gmail.com

${ }^{* * * * *}$ Graduate from Marmara University in 2016, Faculty of Business Administration, Department of Business Administration (lectured in English), sena_ceylan@hotmail.com 


\title{
KONAKLAMA SEKTÖRÜNDE BÜYÜK VERİ ARACILIĞIYLA SEKTÖREL REKABETTE KÜLTÜREL FARKLILIKLARIN KEŞFI
}

\begin{abstract}
Öz
2014-2016 yılları için Pazarlama Bilim Enstitüsü (MSI), "Veri Bakımından Zengin Ortamlarda Pazarlama Analitiğini Geliștirme" konusunu "Birinci Derecede Öncelikli" konu olarak belirlemiștir. Müşterilerin deneyimlerini inceleyerek onları anlamak, uzun dönemde kârlı müşteri ilişkileri oluşturabilmek için önemlidir. Konaklama sektöründe ziyaretçiler, deneyimlerini internetteki seyahat sitelerinde paylaşarak "büyük veri” olarak adlandırılan büyük miktarda veri yaratmaktadır. Eğer bu deneyimler analiz edilip bilgiye dönüştürülebilirse rekabet avantajı sağlanabilir, bu amaçla veri madenciliği araçları büyük veri setlerindeki gizli örüntü ve ilişkileri bulmak için kullanılır. Dolayısıyla bu çalışmanın amacı, büyük veri yardımıyla konaklama sektöründe kültürel farklılıkları keşfetmektir. $\mathrm{Bu}$ amaçla, müşterilerin Londra ve Tokyo'ya ilişkin "booking.com" üzerinden toplanan çevrimiçi görüşleri (her bir şehirden 500 olmak üzere toplam 1000 müşteri görüşü) olumlu ve olumsuz faktörler üzerinden bir veri madenciliği aracı olan metin madenciliği kullanımıyla analiz edilmiştir. Ardından, bulgular Hertzberg'in İki Faktörlü Motivasyon Teorisi’ne ve kültürel farklılıklara göre incelenmiştir. Ek olarak, otel yöneticilerine sektörlerinde rekabet avantajı kazanabilmeleri için yönetimsel çıkarımlar sunulmuştur.
\end{abstract}

Anahtar Kelimeler: Büyük Veri; Metin Madenciliği; Hertzberg’in İki Faktörlü Motivasyon Teorisi; Turizm Pazarlaması

\section{Introduction}

Nowadays, consumers can share their experiences and thoughts online, and they can take advantage of the reviews of others. In this way, huge volumes of textual data -called eWOM - are created by from the reviews, and these data provide precious information for businesses (Dirsehan, 2015). Every day, 2.5 quintillion bytes of data are created and $90 \%$ of the data in the world today were produced within the past two years (IBM, 2012). These huge and unstructured or semistructured data are called "big data" and can be understood and analyzed by using data mining technique, which is one way of finding hidden patterns and relationships in a large data set. Analyzing the big data provides information about consumers to the hospitality sector in order to understand their behavior and build profitable relationships. This study attempts to analyze travelers' motivators by using data mining tools to obtain improved marketing decision making for hotel managers.

\section{Literature Review}

In today's information age, customers can be heard via their comments on travel websites that provide big data (Dirsehan, 2016). IBM’s 2012 Big Data @ Work Survey of 1144 professionals found that 63 percent of respondents reported that the use of information including big data and analytics 
is creating a competitive advantage for their organizations (Kaplan, 2013). Social media sites, smart phones, and other consumer devices, including PCs and laptops, have allowed billions of individuals around the world to contribute to the amount of big data available. However, big data is not just about the volume of data but also its variety and velocity (Akerkar, 2012). Up until about five years ago, most data collected by organizations consisted of transaction data that could easily fit into rows and columns of relational database management systems. Since then, there has been an explosion of data from Web traffic, e-mail messages, and social media content (tweets, status messages), as well as machine-generated data from sensors (used in smart meters, manufacturing sensors, and electrical meters) or from electronic trading systems. These data may be unstructured or semistructured; thus, they are not suitable for relational database products that organize data in the form of columns and rows (Laudon \& Laudon, 2014). So, to analyze these types of data, data mining is used as a way of finding hidden patterns and relationships in a large data set. The major features of data mining are classification, clustering, regression, and association rules. These techniques can be used in very specific decision-making and analyzing systems. More specifically, as a data mining tool, text mining is very useful and a popular application in the recent years for business and e-WOM platforms. It provides businesses the ability to gain a competitive advantage by finding hidden patterns and meanings in massive amounts of unstructured textual data. Certainly, text mining derives much of its inspiration and direction from seminal research on data mining. Therefore, it is not surprising to find that text mining and data mining systems evince many high-level architectural similarities. For instance, both types of systems rely on preprocessing routines, pattern-discovery algorithms, and presentation-layer elements such as visualization tools to enhance the browsing of answer sets. Further, text mining adopts many of the specific types of patterns in its core knowledge discovery operations that were first introduced and vetted in data mining research (Feldman \& Sanger, 2007). Data mining techniques can be proposed to hotel managers to bolster their customer retention strategy and to understand their customers' preferences and the ways to interact with them (Min et al., 2002). In travel and tourism, where planning, spontaneity, risk, adventure, and expectation all weigh so heavily on the journey, big data offers huge gain (Jouan, 2014). The benefits of big data for travel providers and travelers are explored, including better decision support, new products and services, better customer relationships, and cheaper and faster data processing (Davenport, 2013).

"RapidMiner" is a software platform developed by a company of the same name that provides an integrated environment for machine learning, data mining, text mining, predictive analytics, and business analytics. It is used for business and industrial applications as well as for research, education, training, rapid prototyping, and application development, and it supports all steps of the data mining process, including results visualization, validation, and optimization (Hofmann \& Klinkenberg, 2013). It is a useful application for data mining. There are many similar applications, but it was used in this project because its starter edition is free.

According to the MasterCard 2015 Global Destination Cities Index (Hedrick-Wong \& Choong, 2015), the most popular destination for tourists in the world is London, and it is compared with an Asian country for observing some cultural differences. Tokyo is the second city of the Fastest Growing Destination Cities within the Top 20 (2009-2015 CAGR) chart, so it was decided 
that Tokyo would be the second city to be compared. Before analyzing travelers' reviews, the cultural differences of selected cities are determined according to Geert Hofstede's Six Cultural Dimensions. Hofstede analyzed cultures of countries along six dimensions. These are Power Distance, Individualism vs. Collectivism, Masculinity vs. Femininity, Uncertainty Avoidance, Long-Term vs. Short-Term Orientation, and Indulgence vs. Restraint.

Power Distance is related to the different solutions to the basic problem of human inequality. Uncertainty Avoidance is related to the level of stress in a society in the face of an unknown future. Individualism vs. Collectivism is related to the integration of individuals into primary groups. Masculinity versus Femininity is related to the division of emotional roles between women and men. Long Term versus Short Term Orientation is related to the choice of focus for people's efforts: the future or the present and past. Indulgence versus Restraint is related to the gratification versus control of basic human desires related to enjoying life (Hofstede, 2011). Hofstede rated 58 countries on each dimension with a scale from 1 to 100 . The country scores of Japan and the United Kingdom are shown in Figure 1.

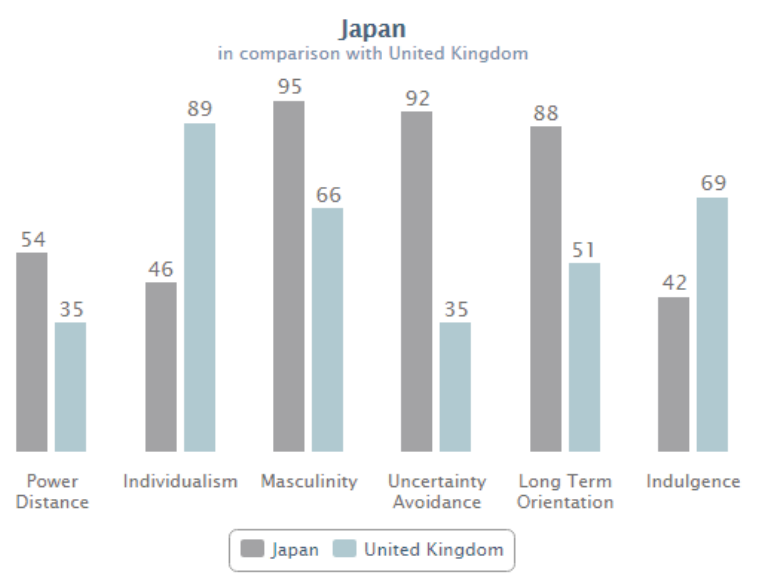

Figure I: Hofstede Scores Comparison of Japan and United Kingdom Source: http://geert-hofstede.com/japan.html

\section{Methodology}

\section{Sample and Data Collection}

Nowadays, technological advancements enable new techniques in marketing research. In today's digital information environment, customer data are recorded and stored in digital data warehouses. A data warehouse is defined by Hair et al. (2009) as a "logical aggregation of information stored in a single location" (Hair et al., 2009). The reviews consist of both positive and negative comments forming the data warehouse in this study, and they were grouped in order to analyze their role in consumer satisfaction. A total of 1000 customer reviews (500 for each city, 
each review consists of both positive and negative comments) were selected randomly and are divided into two groups of "Satisfaction" and "Dissatisfaction" in an Excel file. The reviews are collected from the website "Booking.com," since it collects both positive and negative comments separately from every visitor at the same time.

Data that can be extracted from Booking.com include: traveler's name (if provided), traveler's nationality, travel type, traveler's gender (if provided), traveler's age (if provided), comment dates, traveler's review scores, travelers' positive comments, traveler's negative comments, names of the hotels to be reviewed, hotel stars, and hotel's total review scores (Dirsehan, 2016).

A total of 1000 positive and 1000 negative comments from two destinations are included in the data warehouse. A maximum of 30 comments for the same hotel are considered.

\section{Data Preparation and Measurement}

The satisfied and dissatisfied comments from Tokyo and London were copied from Excel and pasted into separate WordPad files, and these files were again included in different folders with the same names: Satisfaction and Dissatisfaction. These folders were uploaded into RapidMiner - a data mining tool - in order to analyze the data by using operations to determine how many times the factors occur in positive and negative comments.

By using some operators like "Tokenize," "Stem (Porter)," "Filter Stopwords," and "Generate $\mathrm{n}$-Grams we determined how many times the factors occur in positive and negative comments. First, the "Process Documents from Files" operator was used in order to display the "Edit List" option to upload our folders labeled as Satisfaction and Dissatisfaction. Then the Tokenize operator was used to analyze the data on the "Word List" window with "Total Occurrences," "Document Occurrences," and "Positive" and "Negative" columns. According to these titles, words can be listed from most to least frequent. The total occurrences column shows how many times the word occurred in that document, and the document occurrences indicate in how many documents the word exists. The second operator is Filter Stopwords. The main purpose of this operator is to provide an understanding of how many times the word occurs; for example, "the" 1565 times, "and" 1020 times, "to" 774 times, "a" 600 times, etc. The third operator's name is Stem (Porter), which is used for reducing words to their basic roots; for instance, clean-,cleaner, cleaning, cleanliness, etc. The last operator, which is Generate n-Grams, analyzes a set of cooccurring words rather than analyzing them separately; for instance, "service quality" instead of "service" and "quality."

\section{Sample Characteristics}

Some descriptive statistics from the travelers whose reviews are analyzed are shown in Tables 1 and 2. 
Table I. Traveler's Characteristics for Tokyo and London Reviews

\begin{tabular}{ccc}
\hline & \multicolumn{2}{c}{ Number of Reviews Analyzed for } \\
\cline { 2 - 3 } & Tokyo & London \\
\hline Traveler's Gender & & \\
\hline Female & 192 & 136 \\
Male & 285 & 164 \\
Not indicated & 23 & 200 \\
\hline Traveler's Type & & \\
\hline Solo & 122 & 104 \\
Family & 134 & 206 \\
Group & 65 & 52 \\
Couple & 179 & 138 \\
\hline Traveler's Trip Type & & 435 \\
\hline Leisure Trip & 447 & 65 \\
Business Trip & 53 & 500 \\
\hline TOTAL & 500 & \\
\hline
\end{tabular}

Table 2. Nationalities of Travelers Whose Reviews are Analyzed

\begin{tabular}{cccccccccc}
\hline \multicolumn{7}{c}{ Nationalities of Travelers and Number of Reviews (Tokyo) } \\
\hline Australia & 89 & Hong Kong & 32 & Netherlands & 5 & South Africa & 2 & Dominican & 1 \\
Azerbaijan & 1 & India & 5 & New Zealand & 5 & South Korea & 7 & Finland & 1 \\
Belgium & 6 & Indonesia & 17 & Norway & 1 & Spain & 5 & France & 8 \\
Brazil & 2 & Iran & 1 & Philippines & 16 & Sweden & 4 & Germany & 8 \\
Bulgaria & 1 & Ireland & 3 & Poland & 3 & Switzerland & 7 & Gibraltar & 1 \\
Cambodia & 1 & Israel & 7 & Portugal & 2 & Taiwan & 16 & Greece & 1 \\
Canada & 11 & Italy & 3 & Qatar & 9 & Thailand & 20 & Guam & 1 \\
Chile & 1 & Japan & 20 & Romania & 1 & Turkey & 5 & Hungary & 1 \\
China & 16 & Kuwait & 1 & Saudi Arabia & 8 & United Kingdom & 45 & Singapore & 28 \\
Croatia & 1 & Macau & 3 & Mauritius & 1 & UAE & 11 & Czech Rep & 1 \\
Cyprus & 1 & Malaysia & 14 & Myanmar & 1 & USA & 38 & Denmark & 1 \\
\hline \multicolumn{7}{c}{ Nationalities of Travelers and Number of Reviews (London) } & & \\
\hline Australia & 32 & Hong Kong & 8 & Netherlands & 7 & Africa & 3 & Estonia & 3 \\
Iceland & 2 & Jersey & 2 & New Zealand & 9 & Egypt & 5 & Finland & 1 \\
Belgium & 3 & Nigeria & 4 & Norway & 3 & Spain & 1 & France & 5 \\
Brazil & 2 & Kuwait & 17 & Austria & 1 & Sweden & 4 & Germany & 6 \\
Bulgaria & 2 & Luxembourg & 1 & Seychelles & 1 & Switzerland & 6 & Argentina & 2 \\
India & 5 & Oman & 2 & Portugal & 1 & Uganda & 1 & Greece & 3 \\
Canada & 6 & Italy & 2 & Qatar & 12 & Thailand & 5 & Pakistan & 1 \\
Ireland & 8 & Japan & 1 & Denmark & 2 & Turkey & 18 & Hungary & 1 \\
China & 4 & Russia & 1 & Saudi Arabia & 28 & United Kingdom & 199 & Czech Rep & 1 \\
Kazakhstan & 1 & Man Island & 1 & Bahrein & 3 & UAE & 12 & USA & 36 \\
Cyprus & 3 & Malaysia & 7 & South Africa & 6 & & & & \\
\hline
\end{tabular}




\section{Research Findings}

\section{Satisfaction and Dissatisfaction Stories for Tokyo}

After arranging the data warehouse, the main objective is to explore the factors driving customers to write positive and negative comments. The most frequent words in the satisfaction and the dissatisfaction stories for Tokyo are indicated in Table 3 and Table 4.

According to the satisfaction stories for Tokyo, the uncontrollable factors (Tokyo-related factors) of Tokyo are "Location," “Tokyo," "Airport," and "Station." The controllable factors can be divided into three attributes. These are staff-related, equipment-related, and other differentiations. Staffrelated factors are "Friendli-, staff, servic-, help-, and English." Equipment-Related factors are "garden and spa," and the other differentiating factors are "comfort-, and clean-." At the top of the table, descriptive adjectives are "good, quiet-, and nice," according to the most frequent occurrences.

The second table includes the dissatisfaction stories that have the most frequent occurrences in the dissatisfaction reviews.

Table 3. Words That Occurred in Satisfaction Stories for Tokyo

\begin{tabular}{|c|c|c|c|c|}
\hline \multicolumn{2}{|c|}{ Classification } & Word & $\begin{array}{c}\text { Times Occurred } \\
\text { in the Satisfaction } \\
\text { Reviews }\end{array}$ & $\begin{array}{c}\text { Times Occurred in } \\
\text { the Dissatisfaction } \\
\text { Reviews }\end{array}$ \\
\hline \multirow{3}{*}{\multicolumn{2}{|c|}{ Descriptive Adjectives }} & Good & 79 & 23 \\
\hline & & Quiet & 9 & 2 \\
\hline & & Nice & 35 & 8 \\
\hline \multirow{4}{*}{$\begin{array}{c}\text { Unconrollable } \\
\text { Factors }\end{array}$} & \multirow{4}{*}{$\begin{array}{c}\text { Tokyo-Related } \\
\text { Attributes }\end{array}$} & Tokyo & 27 & 11 \\
\hline & & Location & 102 & 27 \\
\hline & & Airport & 8 & 4 \\
\hline & & Station & 28 & 20 \\
\hline \multirow{9}{*}{ Controllable Factors } & \multirow{5}{*}{$\begin{array}{l}\text { Staff-Related } \\
\text { Attributes }\end{array}$} & Friendli- & 35 & 6 \\
\hline & & Help- & 48 & 9 \\
\hline & & Staff & 87 & 38 \\
\hline & & Servic- & 43 & 28 \\
\hline & & English & 8 & 11 \\
\hline & Equipment-Related & Garden & 13 & 7 \\
\hline & Attributes & Spa & 11 & 6 \\
\hline & \multirow{2}{*}{ Other Differentiators } & Clean- & 23 & 21 \\
\hline & & Comfort- & 20 & 8 \\
\hline
\end{tabular}


Table 4. Words That Occurred in Dissatisfaction Stories for Tokyo

\begin{tabular}{ccc}
\hline Word & $\begin{array}{c}\text { Times Occurred in the Satisfaction } \\
\text { Reviews }\end{array}$ & $\begin{array}{c}\text { Times Occurred in the } \\
\text { Dissatisfaction Reviews }\end{array}$ \\
\hline Smell- & 0 & 14 \\
Bath- & 8 & 18 \\
Breakfast & 21 & 62 \\
Facil- & 13 & 17 \\
Restaur- & 18 & 27 \\
Bed- & 15 & 37 \\
Check & 1 & 36 \\
Price- & 4 & 22 \\
Room- & 110 & 215 \\
Lobby & 2 & 14 \\
Shower- & 1 & 9 \\
Connect- & 3 & 10 \\
English- & 8 & 11 \\
Gym & 6 & 9 \\
WiFi & 3 & 30 \\
Pool & 5 & 14 \\
Pillow & 4 & 12 \\
Small Rooms & 0 & 19 \\
\hline
\end{tabular}

\section{Satisfaction and Dissatisfaction Stories for London}

The most frequent words in the satisfaction and dissatisfaction stories for London are indicated in Table 5 and Table 6.

Table 5. Words That Occurred in Satisfaction Stories for London

\begin{tabular}{|c|c|c|c|c|}
\hline \multicolumn{2}{|c|}{ Classification } & Word & $\begin{array}{c}\text { Times Occurred } \\
\text { in the Satisfaction } \\
\text { Reviews }\end{array}$ & $\begin{array}{c}\text { Times Occurred in } \\
\text { the Dissatisfaction } \\
\text { Reviews }\end{array}$ \\
\hline \multirow{3}{*}{\multicolumn{2}{|c|}{ Descriptive Adjectives }} & Good & 96 & 18 \\
\hline & & Quiet- & 10 & 1 \\
\hline & & Nice & 44 & 4 \\
\hline \multirow{4}{*}{$\begin{array}{l}\text { Unconrollable } \\
\text { Factors }\end{array}$} & \multirow{4}{*}{$\begin{array}{l}\text { London-Related } \\
\text { Attributes }\end{array}$} & London & 21 & 9 \\
\hline & & Location & 260 & 9 \\
\hline & & Station & 46 & 3 \\
\hline & & Underground & 10 & 1 \\
\hline \multirow{10}{*}{ Controllable Factors } & \multirow{4}{*}{$\begin{array}{l}\text { Staff-Related } \\
\text { Attributes }\end{array}$} & Friendli- & 84 & 7 \\
\hline & & Help- & 55 & 10 \\
\hline & & Staff & 164 & 56 \\
\hline & & Recept- & 15 & 1 \\
\hline & \multirow{2}{*}{$\begin{array}{l}\text { Food-Related } \\
\text { Attributes }\end{array}$} & Food & 15 & 10 \\
\hline & & Restaurant & 15 & 3 \\
\hline & \multirow{2}{*}{$\begin{array}{c}\text { Equipment-Related } \\
\text { Attributes } \\
\end{array}$} & Servic- & 25 & 20 \\
\hline & & Facilities & 24 & 5 \\
\hline & \multirow{2}{*}{ Other Differentiators } & Clean- & 59 & 28 \\
\hline & & Comfort- & 34 & 4 \\
\hline
\end{tabular}


For London, the uncontrollable factors (London-related factors) are "Location, London, Underground and Station." In the controllable factors, the staff-related factors are "Friendli-, staff, recept-, and help-." Food-Related factors are "restaurant and food," equipment-related factors are "facilities and servic-," and the other differentiating factors are "comfort-, and clean." At the top of the table, the descriptive adjectives are "good, quiet- and, nice," according to the most frequent occurrences.

Table 6. Words That Occurred in Dissatisfaction Stories for London

\begin{tabular}{ccc}
\hline Word & $\begin{array}{c}\text { Times Occurred in the Satisfaction } \\
\text { Reviews }\end{array}$ & $\begin{array}{c}\text { Times Occurred in the } \\
\text { Dissatisfaction Reviews }\end{array}$ \\
\hline Smell- & 2 & 14 \\
Bath- & 15 & 42 \\
Bed- & 39 & 58 \\
Check & 8 & 33 \\
Price- & 17 & 22 \\
Breakfast & 63 & 76 \\
Room- & 106 & 252 \\
Shower- & 12 & 21 \\
WiFi & 8 & 31 \\
Space & 4 & 8 \\
Carpet & 1 & 14 \\
Lift & 1 & 29 \\
Nois- & 7 & 39 \\
Toilet & 1 & 15 \\
\hline
\end{tabular}

\section{Discussion and Implications}

The results obtained by using operators were interpreted according to Hertzberg's TwoFactor Theory. "The theory suggests the existence of two types of factors concerning the problem formulation i.e. satisfaction and motivation at work, namely Hygiene and Motivating factors" (Peneva, 2013). Dissatisfiers or hygiene factors as well as maintenance factors lead to dissatisfaction if below the minimum expected standard. The satisfiers or motivator factors, as termed by Herzberg, are factors that contribute to the satisfaction of the guests and that will not lead to dissatisfaction without the factors (Chan \& Baum, 2007).

For Tokyo, the motivator factors consist of "friendly, helpful-, garden, location-, airport, station, and spa," according to Herzberg's Theory. For instance, if the staff is helpful and friendly, the consumers can be adequately motivated, but if there is no such staff, consumers' satisfaction won't reduce. In addition, the other staff-related factor, "staff," is analyzed in the group of "Hygiene Factors" because it is obligatory for every hotel and will directly affect the consumers' dissatisfaction. For London, the motivators are "station, underground, location-, friendly, and facilities." Also, the words that are in the "Dissatisfaction Stories" table for both cities are our 
"Hygiene Factors" according to Herzberg's Theory. Because of the inadequacy of these factors, they lead to customers' dissatisfaction. According to the research findings, firstly, hotel managers should focus on the elimination of dissatisfaction factors. For instance, for both London and Tokyo, the hotels leverage central Wi-Fi for all parts because of the visitors' complaints. They should work with companies that provide a successful telecommunication substructure for better Wi-Fi service. They could redesign showers according to the interpretation of in webpage reviews. They should train their staff to ensure the proper hygiene of rooms, showers, and bathrooms for internal audit. Moreover, they could work with subcontractor companies. The price of the hotels in both cities is not satisfied by visitors, and they should make some price corrections according to their visitors' expectations. In addition, the hotels in both cities have check-in problems. The staff working in reception can be trained, or required technology can be developed.

Some differences are detected between the hotels in Tokyo and London based on the dissatisfaction results of the findings. For example, the hotels in Tokyo could be enriched with facilities. For London, ensuring sound insulation is required for providing a quiet space, and the rooms' air conditioning could be changed in order to avoid smells. Otherwise, cultural differences influence the satisfaction or dissatisfaction of the visitors. For instance, as already known, for centuries the English language has been pursued as a diffusion policy with the entire world, so English has developed to become a global language. In the tourism industry, London hotels take advantage of the English language, but there is an English-speaking problem in Tokyo for the staff, so multilingual or higher educated staff could be employed. Tokyo has wider traditional cuisine than London, but the travelers are dissatisfied with the restaurant and foodrelated factors. Travelers may be wary of traditional foods and may tend toward familiar tastes. Hence, the hotels in Tokyo should serve more global tastes to satisfy their consumers. According to Japanese culture, the art of landscaping, "Zen," the art of flower arrangement, "Ikebana," and the art of growing miniature trees, "Bonsai," are traditional arts, so the gardens of Tokyo hotels are satisfaction factors according to visitors' reviews. In addition, the hotels in Tokyo have a Far East massage culture that provides high-quality services in its spa centers. Therefore, thanks to these factors, Tokyo hotels take advantage in the tourism industry. Moreover, according to the satisfaction and dissatisfaction stories of Tokyo and London, most of the factors are related to the hotels' physical characteristics; for example, room, restaurant, facilities, etc. Therefore, hotel managers should conceive creative power for physical facilities. This will increase value of perceived service. In Figure 1, the United Kingdom scores 89 on the individualism dimension, but Japan has a collectivist culture with 46. A great number of Japanese hotels take harmony as their motto (Hasegava, 2009). The hospitality sector is people oriented, so the individual or collectivist tendency of the hotel manager shapes his/her management style, and it is important for the motivation of employees. Highly motivated employees are more successful and effective. Besides, as shown in Figure 1, Japan is one of the most masculine societies in the world. In corporate Japan, you see that employees are most motivated when they are fighting in a winning team against their competitors. What you also see as an expression of masculinity in Japan is the drive for excellence and perfection in its material production (monodukuri) and material services 
(hotels and restaurants) and presentation (gift wrapping and food presentation) in every aspect of life (The Hofstede Center, 2016). For this reason, training and directing Japanese employees in order to increase the quality of perceived service might be easier than English employees in the hotels. At this point, "Servqual Analysis" is suggested to the hotel management. Servqual Analysis is a method for measuring service quality. By using this method, the hotel management can analyze differences between the expected and perceived quality of service for customers (Filiz \& Kolukısaoğlu, 2013). Thus, the hotel management can develop an ideal quality of services.

For Tokyo, "small_rooms" are detected in dissatisfaction stories. At 92, Japan is one of the most notable uncertainty avoidance countries on earth, as shown in Figure 1. This is often attributed to the fact that Japan is constantly threatened by natural disasters such as earthquakes, tsunamis (This is a Japanese word used internationally), typhoons, and volcano eruptions. Under these circumstances, the Japanese have learned to prepare themselves for any uncertain situation (The Hofstede Center, 2016). Therefore, Japanese people believe that by living a minimal lifestyle with small rooms and less belongings, they may increase their chances of surviving. On the other hand, the UK has a low score on uncertainty avoidance and also a high score on the indulgent dimension. It explains the UK's positive tendency positive tendency toward living in the moment rather than living a minimal lifestyle.

To sum up, the hotels in the hospitality sector must be aware of these topics that are obtained thanks to the data mining tools. Hotel managers should try to strengthen their deficiencies in order to reduce customer dissatisfaction. Also, for better marketing decision making, they should focus on the motivators to improve their strengths that lead to customer satisfaction in order to gain competitive advantage and create customer loyalty. 


\section{References}

Akerkar, R., (2012) "Big Data \& Tourism. To promote innovation and increase efficiency in the tourism sector."(TMRF Report 11-2012), Big Data \& Tourism. To Promote Innovation and Increase Efficiency In The Tourism Sector.

Chan J. \& Baum T., (2007) "Determination of Satisfiers and Dissatisfiers Using Herzberg's Motivator and Hygiene Factor Theory: An Exploratory Study” Tourism, Culture \& Communication, 7 (2), 117-131.

Davenport, T.H. (2013) "At the Big Data Crossroads: Turning Towards a Smarter Travel Experience". Amadeus IT Group Report, Available at: http://amadeusblog.com/wp-content/uploads/AmadeusBig-Data-Report.pdf, Accessed 01.04.2016.

Dirsehan, T. (2015). "An Application of Text Mining to Capture and Analyze eWOM: A Pilot Study on Tourism Sector" In: S. Rathore, \& A. Panwar (Eds.), Capturing, Analyzing, and Managing Word-ofMouth in the Digital Marketplace, Hershey: IGI Global, 168-186.

Dirsehan, T. (2016) "Text Mining in the Hospitality Sector to Extend the Motivation Theory". International Marketing Trends Conference, Venice, Available at: http://www.marketing-trends-congress.com/ archives/2016/pages/PDF/DIRSEHAN.pdf, Accessed 01.04.2016.

Feldman, R., \& Sanger, J. (2006). The Text Mining Handbook: Advanced Approaches in Analyzing Unstructured Data. Cambridge: Cambridge University Press.

Filiz, Z. \& Kolukısaoğlu, S. (2013). “Servqual Yöntemi ve Bir Hizmet İşletmesinde Uygulaması”, Dumlupınar Üniversitesi Sosyal Bilimler Dergisi, EYİ 2013 Özel Sayıs1, 253-266.

Hair, J., Robert, B. R., \& Ortinau, D. (2009). Marketing Research in a Digital Information Environment (4th ed). New York: McGraw Hill/Irwin.

Hasegava, J. (2009). Motivation Level of Japanese Hotel Managers and the Effects of Variables on Their Levels of Managerial Motivation, 184-195.

Hedrick-Wong Y. \& Choong D. (2015), "MasterCard 2015 Global Destination Cities Index", Available at: https://newsroom.mastercard.com/wp-content/uploads/2015/06/MasterCard-GDCI-2015-FinalReport1.pdf, Accessed 01.04.2016.

Hofmann M. \& Klinkenberg R. (ed) (2014), RapidMiner: Data Mining Use Cases and Business Analytics Applications (Chapman \& Hall/CRC Data Mining and Knowledge Discovery Series), CRC Press, Taylor \& Francis Group.

Hofstede, G. (2011). "Dimensionalizing Cultures: The Hofstede Model in Context", Online Readings in Psychology and Culture, 2(1).

International Business Machines Corporation (IBM) (2012), IBM Annual Report, Available at: https://www. ibm.com/annualreport/2012/bin/assets/2012_ibm_annual.pdf, Accessed 01.04.2016.

Jouan, C. (2014) "Big Data Insight for Travel and Tourism", 14th WTTC (World Travel \& Tourism Council) Global Summit, Hainan, China. Available at: https://www.wttc.org/research/other-research/bigdata-the-impact-on-travel-tourism/, Accessed 01.04.2016.

Kaplan, M. (2013) "Analyzing Big Data: The Path to Competitive Advantage". Ziff Davis B2B White Paper.

Laudon, K., \& Laudon, J. (2014). Management Information Systems: Managing the Digital Form (13th Global Ed), USA: Pearson Education Limited.

Min, H., Min, H., \& Emam, A. (2002). "A Data Mining Approach to Developing The Profiles of Hotel Customers", International Journal of Contemporary Hospitality Management, 14(6), 274-285.

Peneva, M.R. (2013). The Importance of Employee Satisfaction to Hotel's Operations, Thesis Submitted to the Department of Service Hospitality and Tourism Management, University College Nordjylland.

The Hofstede Center, Cultural Dimensions (n.d.), Available at: https://geert-hofstede.com/countries.html, Accessed 01.04.2016. 